\title{
An investigation into Designing Smart city in Accordance with Designing for Children toward Child-Friendly Smart Cities
}

\author{
Amir Rastegar, Mazdak Irani, Behzad Shojaedingivi \\ Politecnico di Milano, Italy \\ Master of urban planing and policy design \\ (Corresponding author) \\ PhD Candidate, University of Sydney, Sydney, Australia \\ M.Arch. University of Tehran
}

\begin{abstract}
The process of urban planning should be multi-dimensional and comprehensive meaning that it takes into consideration all groups of people especially less able ones. Children are one of these groups who should be taken into consideration more in urban planning and urban design. Planning to make cities smart is one of the new approaches in urban design. However, children are often largely ignored in these plans. The researchers of the present study tried to examine the position of children in smart city-related planning. To this end, the concepts of child-friendly cities are dealt with and studied so that its common indexes with the smart city would be extracted hoping that the position of children in smart cities would be considered more. The research method employed in the study is library-based and analytic-descriptive.
\end{abstract}

Keywords: Smart city, Child-Friendly City (CFC), Urban design.

\section{Introduction}

The increasing growth of urban population and dwelling of almost 3,9 billion persons, that is, 54 percent of the whole population in cities and continuation of this trend encounters the future of the earth with urban perspectives more than ever. These spaces will have over 5 billion population in 2025 that is more than 70 percent of the whole world population (Lopez, 2014). This indicates the fast growth of urban dwelling especially in developing countries (Zhao, 2010). Additionally, this considerable process of urban dwelling with automobile orientation not only expands the body of cities but also, destroys agricultural lands and causes irreparable costs on the environment (Reneh Short, 2008, 20). It, however, should be pointed out that growth of a city implies that the city is burgeoning and healthy and any stop in a city population indicates that the city is sick and in recession in different economic, social, cultural, etc. However, it is the very fast growth and horizontal and sprawl expansion of cities that might bring about negative consequences such as destruction of agricultural lands and irreparable costs on the environment (Rahnama \& Hayati, 2012, 72).

\section{Research Question}

The most important research question of the current study is where is the position of children in smart cities planning? To respond it, first, we should know what are features of a smart city? And what features are taken into consideration for urban planning in line with children needs?

\section{Literature Review}


It was in 1970 that the idea of urban planning and transportation and also that of compact cities and societies were offered. After that, the idea of Peter Calthorpe with the name of the urban village, which was based on walking and cycling transportation instead of automobile, was widely welcomed. Another architect named Andres Duany proposed the idea of changing designing rules to elevate the concept of society and reduce the use of the automobile.

"Smart" in its simplest form refers to the ability to learn from the environment and about environment, comprehension, and interaction with it to adapt to the new environment or changes made in the present environment. Accordingly, "smart society" might be regarded as a society in which wise attempts are made to make use of information technology to change the present conditions and improve life and work quality in a considerable and basic scale. The idea of the smart city was largely unknown until Japanese built the city of science (Kansai) in the middle of 1980's and Australians built the MEP city in Adelaide at the end of the 1980's. It was, in fact, since the decades of 1980 and 1990, on which computer and internet were widely used in cities and the issue of cyber space became very important, that urban activities were oriented toward electrical systems and a new approach was created in urban planning and management (Masih Pour \& Akbarian, 2016).

\section{Definition of Key Words}

a) Smart City and Smart Making:

Various and largely interrelated definitions have been offered as with these concepts. As an example, a city is smart when it has an investment in human resource, social investment, and also information technology infrastructures and growth information and has a high life quality and management of its natural resources is wise. A smart city is a city in which different technologies are used to improve the life quality of its citizens (Momeneh and Rostam Pourzelani, 2016). It might also be defined as a city in which technology is used based on a practical approach to life, development and making a better economy. It is a digital city in which citizens have the possibility to make use of smart infrastructure technologies (Momeneh and Rostam Pourzelani, 2016). Smart city can also be defined as a city that elevates the life level and green economy by using technology. It is a city that offers better life quality and better economy by investment and, social and human resources, and also ICT technology (Poursharifi \& Jafari, 2016). It is a city all of its processes and works are done and managed via the newest technologies (Dehnaie, 2013). Smart making is, in essence, part of management science that deals with offering approaches to solve problems (Hassan Pour, Safari, \& Goudarzi, 2016).

The methods are all problem-solving methods. In other words, the offered methods might not be limited to the computer. The problem-solving methods start with knowing the present situation and the existing problems and then deals with the factors causing the problems and examination of the extant facilities to solve them (Sadeghzadeh et al. 2013). Smart city indicates the opening of new concepts in urban planning and urban design. What orients a city toward a smart city is not merely using electrical tools and facilities, but the way of planning and using the tools to improve the life quality of citizens. The smart city has six features namely, "smart society", "smart economy", "smart supervision", "smart transportation", "smart environment", and "smart life" that need technology, human, and fundamental factors. To exit arrearage and fill the digital gap, it is necessary to take steps to strengthen the three factors of making a smart city (technology, human resources, fundamental factors). To do this, three approaches referred to as integration, learning, and the decent ruling has been offered. The government needs to interact with the private sector and civil society to administer its rules and each group should play its role appropriately. Therefore, having a suitable ruling system as the most important strategy for a smart city is considered in urban planning. Extraction of the conceptual interpretations related to the smart city from different sources might also be effective in structural thinking of smart city and its newly born literature (Ghanbari, 2009). 
In our country, Iran, different factors including the unbalanced growth of cities, inefficiency of the urban management system, using managers with unrelated expertise, lack of long-run management, ... have caused urban dwelling to suffer from a set of problems and difficulties. On the other hand, no comprehensive and detailed plan has ever been offered to manage and organize cities in different areas and cities are, in fact, a reflection of urban management failure. Accordingly, it is necessary to make changes in urban managements strategies and it should change from its traditional form into a smart one. Information technology in different branches of sciences might be a great help in making smart cities and buildings (Razzaghi, 2016).

\section{b) Summarization of Smart City Concept:}

There are some common points in different above-mentioned definitions about smart city: Using digital and ICT technology as the main technology in smart city, necessity of providing and preparing required infrastructures, and role of citizens as both the final target of services and participators in making a city smart

c) Child: According to Moin Farsi Dictionary, "child" means young, small, and a kid who has not yet reached puberty (boy or girl) (Kiani \& Esmaeelzadeh Kavaki, 2012).

d) Child-Friendly City (CFC): the concept of CFC generally means that how government agents manage these cities in line with children interests. It also refers to cities in which the basic rights of children such as health, transportation, support, Education, and culture are regarded. These cities are defined on the basis of division and all practical plans concerning children according to which, children are defined as citizens who have certain rights and have right to express their views. A CFC is not merely a good city for children, rather, it is a city that is made by children (Hosseini Ghiasvand \& Soheili, 2015).

\section{Necessity of Examining Smart City}

The industrial revolution (1750-1850) or the illumination era of Europe was the beginning of many inventions and scientific movements (Freidman, 2007, 15). However, pollutions from industrialization caused many crises and damages which, in turn, led to new concepts to control and remove them one of them was the movement of smart city conceptualized at the beginning of the decade of ninety as a solution to deal with prospective probable damages. However, four factors, more than other factors, highlighted the necessity of smart cities presented in the following table and then the pertinent diagrams are offered:

Table 1: Necessity of Examining smart city (Researchers)

\begin{tabular}{|l|l|l|}
\hline Row & Title & Explanation \\
\hline 1 & $\begin{array}{l}\text { Earth Warming and } \\
\text { Weather Changes }\end{array}$ & $\begin{array}{l}\text { Weather changes are obviously a result of Eco-system that creates many } \\
\text { dangers for society and might negatively affect economics as well. Warming } \\
\text { of the earth and weather changes are tightly related to green house gases such } \\
\text { as Carbon Dioxide and Metan produced often by industrial activities (Hitachi, } \\
\text { 2013). }\end{array}$ \\
\hline 2 & Population Growth & $\begin{array}{l}\text { According to predictions, the world population accounts to 9/3 billion } \\
\text { persons in 2050 (UN, World population, 2009) and in 2020 the urban } \\
\text { population will be 51 percent and in 2050 it will be } 67 \text { percent (IBM, A } \\
\text { vision of smarter, 2009). }\end{array}$ \\
\hline 3 & $\begin{array}{l}\text { Urban dwelling } \\
\text { Increase }\end{array}$ & $\begin{array}{l}\text { Estimation of the UN is that in 2020, the urban population in developing } \\
\text { economics will overtake that of village population and in 2050, almost 70 } \\
\text { percent of the world population will live in cities (UN, world population, } \\
\text { 2009). }\end{array}$ \\
\hline
\end{tabular}




\begin{tabular}{|l|l|l|}
\hline 4 & $\begin{array}{l}\text { Natural Resources } \\
\text { Decrease }\end{array}$ & $\begin{array}{l}\text { Reduction of resources and preparation to deal with any damage in the future } \\
\text { might guide us more than ever to make smart cities (Lebcck, 2014) }\end{array}$ \\
\hline
\end{tabular}

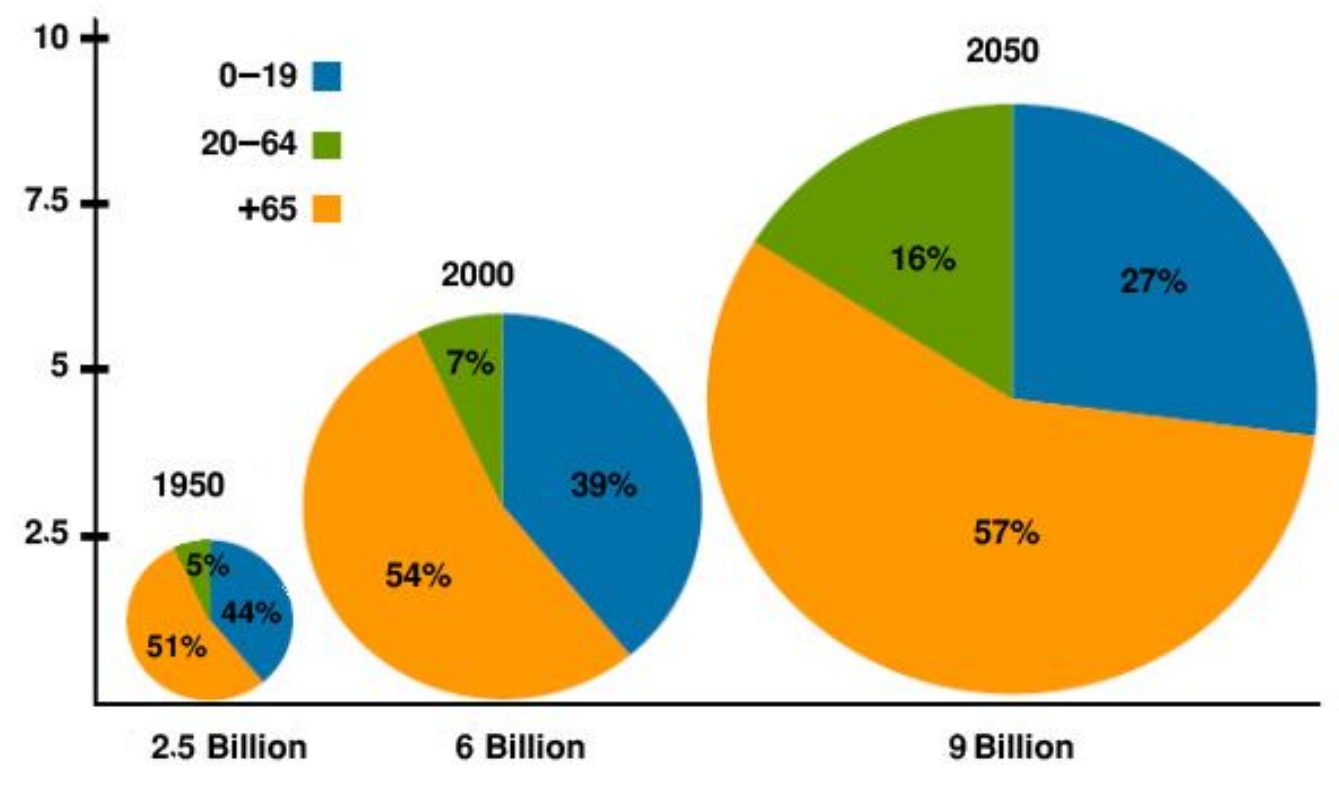

Diagram 1: Population increase and Changes in age Pyramid

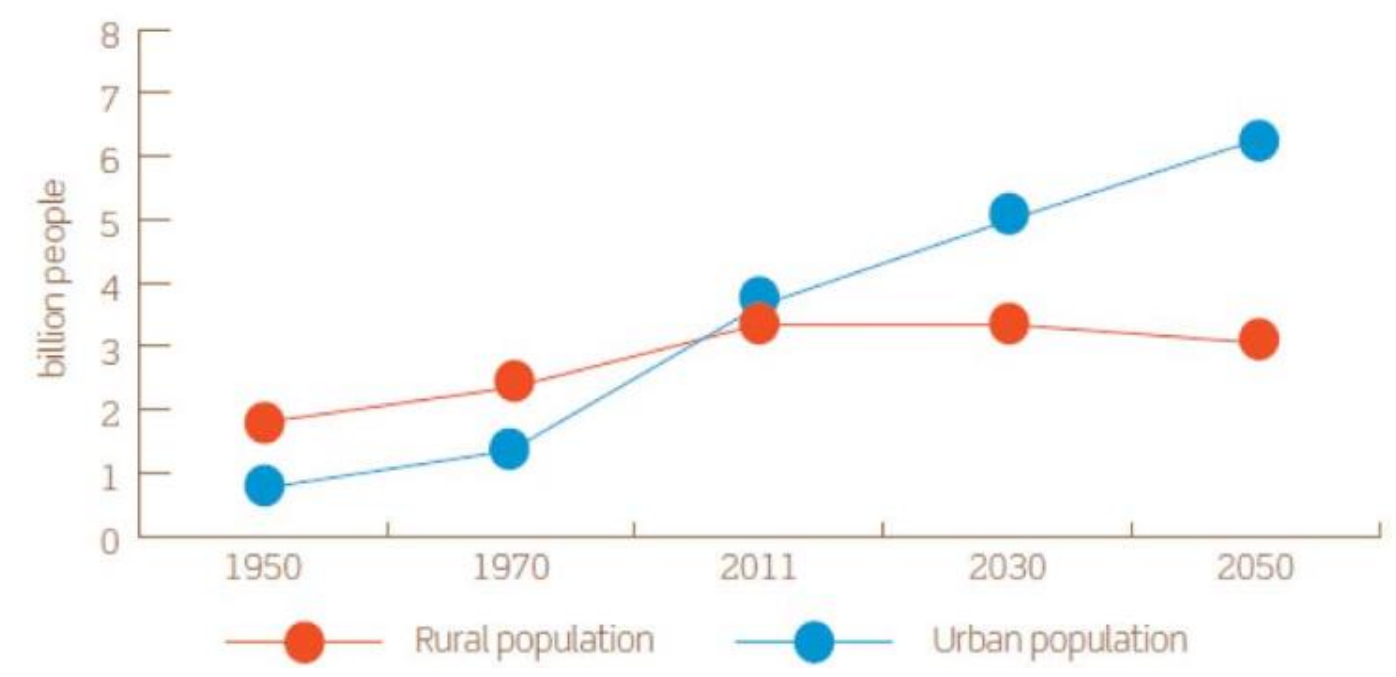

Diagram 2: Increase of urban dwellers in world 


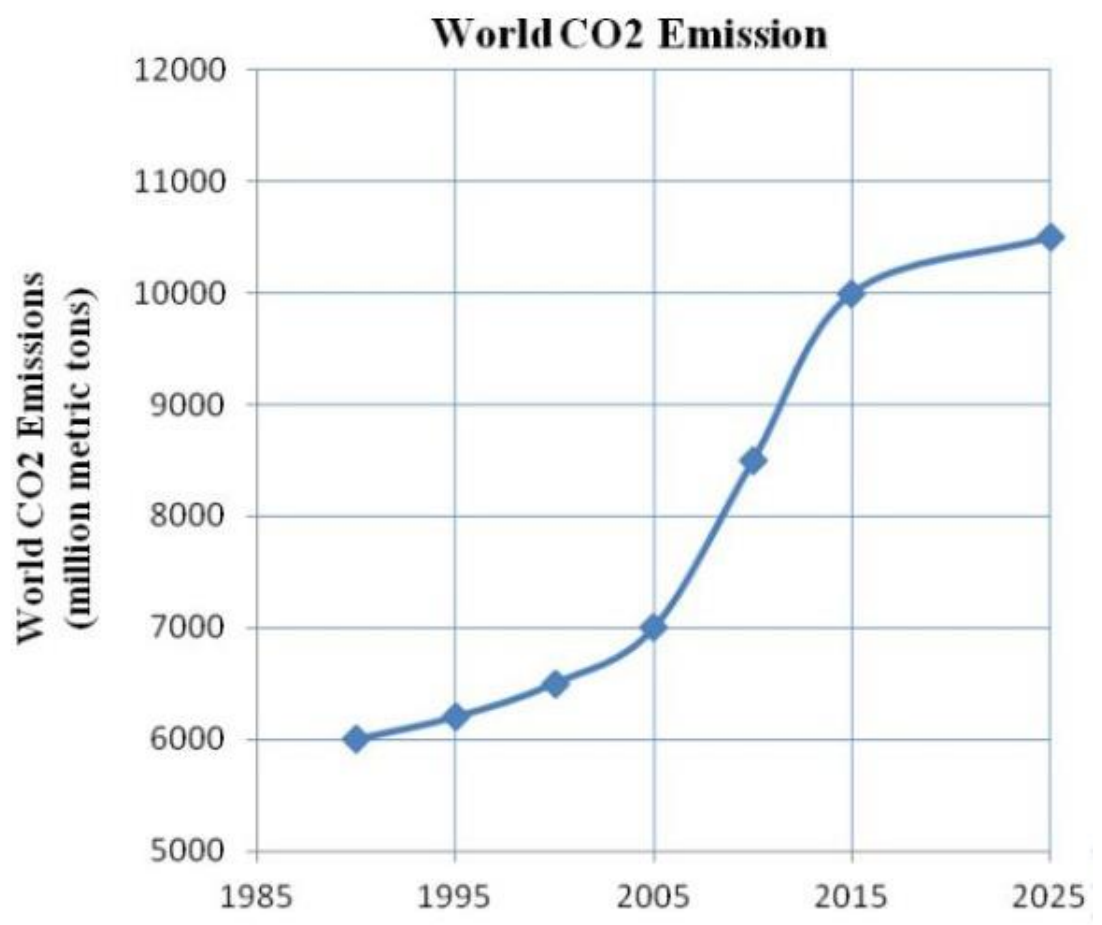

Diagram3: Increase in Carbon Dioxide Production

A healthy city is a city that is suitable for different age groups. From among these groups that are considerable qualitatively and quantitatively is children. A smart city is defined by four precepts each having a role in giving meaning to the smart city:

- Knowledge and knowledge-based development

- Sustainable development

- Boosting the integrity of city

- Citizens participation

At present, many of the world countries are using cyber world strategies to deal with their urban problems especially those that are not solvable in the typical scientific-technical system. These solutions are typically referred to as "digital city" or "electronic government". In these types of strategies, production and offering of services are limited to digital information and convey from higher orders (governmental officials) to lower orders (public people) by digital and electronic ways. The point that should be taken into consideration in "smart city" is using innovative processes in different urban issues to increase citizens' participation in a way that each citizen has a prospective view of the city and its issues and knows him/her responsible to solve the problems. Thus, one of the most salient differences between smart city and the digital city is the capability of the smart city to respond and solve the urban problem of citizens in a lowerto-higher hierarchy. Accordingly, citizens of a smart city feel more responsibility to their city as they are more aware of their city and problems and as a result, they will be producers of services as well. This, in turn, causes the city to be more dynamic and vivid. Additionally, the smart city might be regarded as a venue to form sustained processes of urban development. In line with this, the researcher tries to examine the link between the smart city and child-friendly city in that, as it was already mentioned, this issue has less been taken into consideration in the related literature.

\section{Child-Friendly City (CFC)}

CFC is a city in which child has access to healthy water and other hygienic facilities, his safety is taken into consideration in streets and there is no need to be taken care of by any other person. Furthermore, children, 
in such a city, has freedom and right to express their view points and can participate in different activities (Saeedi, 2009). In fact, the projects of CFC often aim at creating opportunities for children to form and change their environment. To put it another way, CFC designs and plans try to give children their rights, enhance their awareness and group participation, and decrease violence against children (Kamel Nia, 2010). Conducting research concerning CFC in Europe started in 1980. Most of the studies tried to give citizen rights to children and meet their needs and wishes. In line with this, a set of plans were defined all of which focused on three main issues:

- Participatory planning in which children play important roles, like other persons, in formation of the environment

- Children centers in which children are given this chance to collect and meet their requirements

- Giving opportunity and motivation to children in accordance with the independence of CFC features in terms of architecture and urban building without adults' interference (UNICEF, 2005).

Reviewing the related literature shows that there are different purposes and criteria for such an objective. Creating equal participatory opportunities for children helps them to learn how to become aware of their rights and be sensitive about them. In these types of studies, schools always play a determining role. From among other important purposes of CFC plans the following cases might be mentioned: making children interested to follow their rights, practicing cooperation between children and adults, activity to cope with poverty and inequality, participation of disable children, supporting families, encouraging adults to maintain and support children rights, and developing recreational spaces (UNICEF, 2005). According to UNESCO report, in Italy, the first practical governmental planning as with children and young adults was done in 1997 and its most important purposes were:

- Creating a new perspective about a child who emphasizes his/her citizen role; deals with needs and rights of children, and tries to improve the life quality of the new generation

- Creating a new view point in social services section; creating flexible urban space in line with children's needs

- Defining a new role for local governments especially to ease participation process with children and society

- Systematic cooperative planning with all sectors to make effective collective networks more efficient

- Offering a new definition of the city based on being friendly and sustainable and that it is a place in which people might increase their dependence feelings. 
Table 2: Features of CFC

\begin{tabular}{|l|l|l|}
\hline Row & Title & Explanations \\
\hline 1 & $\begin{array}{l}\text { Welfare, security, } \\
\text { and comfort }\end{array}$ & $\begin{array}{l}\text { By making urban facets small, children's security can be increased. Paying } \\
\text { attention to security issues is important as planning a safe urban environment } \\
\text { (Khoshnevis, 2009). }\end{array}$ \\
\hline 2 & Link with Nature & $\begin{array}{l}\text { Children should be in close relationship with natural phenomena including } \\
\text { water, plant, tree, animals, birds, and even insects (Azmoodeh, 2009). }\end{array}$ \\
\hline 3 & Link with history & $\begin{array}{l}\text { Attending an environment with a known identity can strengthen children's } \\
\text { mental memory (Kamel Nia \& Haghir, 2009) }\end{array}$ \\
\hline 4 & $\begin{array}{l}\text { Attraction and } \\
\text { newness }\end{array}$ & $\begin{array}{l}\text { Children, due to their childhood features, considerably ask for newness and } \\
\text { attraction (Ebrahimi et al.2013). }\end{array}$ \\
\hline 5 & $\begin{array}{l}\text { Legibility } \\
\text { One important point in urban space is avoiding wandering feeling and as a result, } \\
\text { insecurity feeling for citizens especially children as children cannot read the } \\
\text { signs (Zekavat, 2006). }\end{array}$ \\
\hline 6 & $\begin{array}{l}\text { Access } \\
\text { facilities }\end{array}$ & $\begin{array}{l}\text { Attention } \\
\text { disable children }\end{array}$ \\
\hline 7 & $\begin{array}{l}\text { If such facilities are not provided, it reduces children's dependence feeling } \\
\text { consideration in the planning (Mardomi \& Ebrahimi, 2013) }\end{array}$ \\
\hline
\end{tabular}

Table 3: Important factors in designing CFC (Rudd, 2008)

\begin{tabular}{|c|c|c|}
\hline Organizational & \begin{tabular}{|l|} 
Cultural \\
\end{tabular} & Environmental \\
\hline $\begin{array}{l}\text { - Commitment to } \\
\text { children's rights } \\
\text { - Participation } \\
\text { - Education } \\
\text { - CFC projects in } \\
\text { education and health } \\
\text { - Organizing } \\
\text { management }\end{array}$ & $\begin{array}{l}\text { - Encouraging the } \\
\text { commemoration of } \\
\text { cultural events, } \\
\text { holding celebrations } \\
\text { - Strengthening } \\
\text { historical and cultural } \\
\text { sites, and cities } \\
\text { cultural heritages }\end{array}$ & $\begin{array}{l}\text { - Reducing } \\
\text { environmental and air } \\
\text { pollution } \\
\text { - Reducing sound and } \\
\text { electro-magnet } \\
\text { pollution } \\
\text { - Ecological guidance } \\
\text { of urban dry garbage } \\
\text { - Space application } \\
\text { and access } \\
\text { - Enhancing green } \\
\text { space } \\
\text { - Changing type of } \\
\text { relationship with } \\
\text { environment and } \\
\text { living creatures } \\
\text { - Encouraging change }\end{array}$ \\
\hline
\end{tabular}

\section{Reasons for Creating CFCs}

Request for making CFCs is rooted in knowing about this issue that cities are, in fact, houses to increase support for children rights. Many of the cities that are not ideal for children have governments that take few steps in this regard (UNICEF, 2006). Creating urban environments that really support children rights requires to examine and study a wide range of topics in different local, national, and global levels. The city should not be regarded merely as a dwelling place of a group of persons and center of contracts; rather, it consists of specific spirits, thoughts, traditions and manners, beliefs, and feelings of persons. To achieve the objectives of CFC and creating an environment suitable for children's needs and interests, children 
themselves should participate in urban planning and this, in turn, needs adults and related officials' attention to the role of children.

(NSW Commission for Children and Young People, 2009)

\begin{tabular}{|c|c|c|}
\hline Factors & Child-friendly societies & Children Health \\
\hline $\begin{array}{l}\text { A) Access to a wide range of } \\
\text { child-friendly services and } \\
\text { activities } \\
\text { B) Independent access to a } \\
\text { variety of child activities and } \\
\text { services } \\
\text { C) Ability to participate in } \\
\text { society participatory } \\
\text { processes }\end{array}$ & $\begin{array}{l}\text { A) Providing independent } \\
\text { access of children to wide } \\
\text { range of suitable social } \\
\text { services and activities in all } \\
\text { ages, abilities, and cultural } \\
\text { backgrounds } \\
\text { B) Providing capacity for } \\
\text { children to be healthy and } \\
\text { access to skill via participation }\end{array}$ & $\begin{array}{l}\text { Activity: Having the ability } \\
\text { to work that leads to control } \\
\text { and ability to be healthy and } \\
\text { doing daily works } \\
\text { independently }\end{array}$ \\
\hline $\begin{array}{l}\text { A) Supports for children's } \\
\text { security } \\
\text { B) Strategies to support } \\
\text { children from physical } \\
\text { damages } \\
\text { C) Features that stimulate } \\
\text { social identification feeling }\end{array}$ & $\begin{array}{l}\text { A) Making the public places of } \\
\text { society safer for children } \\
\text { B) Enhancing children's ability } \\
\text { to feel safe and secure in the } \\
\text { society }\end{array}$ & $\begin{array}{l}\text { Security and safety: Having } \\
\text { feelings of security and } \\
\text { safety to complete } \\
\text { participation in life }\end{array}$ \\
\hline $\begin{array}{l}\text { A) Facilities that give feeling } \\
\text { of happiness and support } \\
\text { B) Availability of creative } \\
\text { and active open spaces } \\
\text { C) Availability of green and } \\
\text { natural spaces }\end{array}$ & $\begin{array}{l}\text { A) Creating spaces in which } \\
\text { children experience happiness } \\
\text { and vividness and success } \\
\text { B) Enhancing situations for } \\
\text { children to access open and } \\
\text { green space }\end{array}$ & $\begin{array}{l}\text { Positive feeling to self: } \\
\text { Feeling that you are a good } \\
\text { person and you are known } \\
\text { by others }\end{array}$ \\
\hline
\end{tabular}

Table 4: Framework of factors to create CFC

\section{Case Study}

This section offers a case in which many attempts were done to plan for children's position in smart cities.

\section{Bhubaneswar}

When smart city announced a list for its own mission in the country, Bhubaneswar

(Capital city of India government from Orissa) was at top of the list. Its basis was on municipalities and the national institution of India to make urban planning. This reflected the needs of children the same as adults' ones as revivals of urban spaces. According to the census in 2011, 75237 under 6 years old children lived in the city. The city was developing so fast that like many other cities of the country led to chaos, unauthorized dwelling, and insufficient infrastructures. From among the problems of children in these cities were the inefficiency of parks, lack of safe pedestrians and streets for children, and lack of suitable transportation (Madakam and others, 2015).

\section{Planning to create Better Cities for Children}

This institute spent 790 thousand euros along with Bhubaneswar development organization and this trend even amounted to 5/1 million euros. The urban affairs national institution was trying to form a ChildFriendly Smart City Center. This was effective in strengthening the development of management framework 
that tries to consider children's perspective. The institution is in cooperation with its counterpart institution in Delhi (Ajiaz and Hoelscher, 2015).

\section{Training 100 Urban Designer for the Center Purposes}

This technical support center started the work by training 100 urban designers and urban planners and announced it as instruction and regulations (Bartlett, 2002).

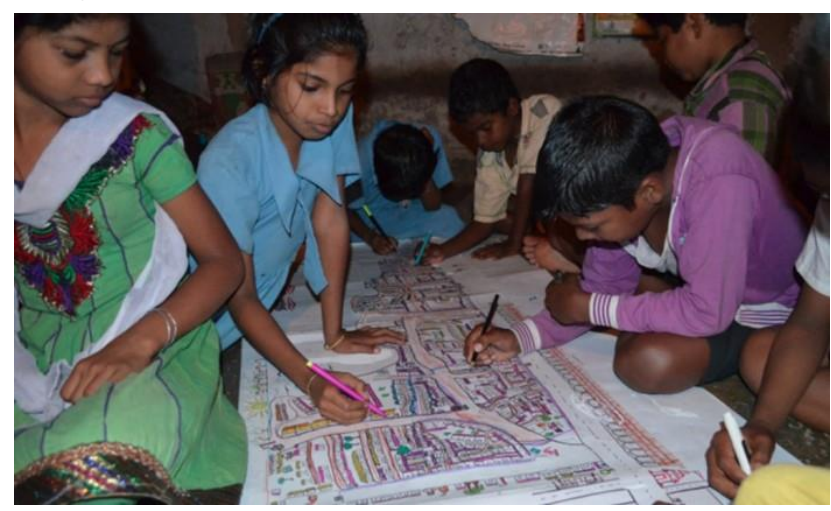

Figure 1: Children's participation in smart city (India)

This helps that huts change into planned towns with necessary facilities for children's life and recreation the most important of which are safe play field, parks, open public spaces, schools, health care centers, easy access to public transportation, bright pathways, traffic improvement especially in front of schools.

\section{Conclusion}

As it was already mentioned, one of the most important purposes of the present study was to extract commonalities between the smart city and CFC so that a set of suggestions might be offered for better planning of children's position in smart cities. Generally, children friendly

cities, which were already referred to as CFC, were called in combination with Smart Child-Friendly Cities (SCFC). In fact, a city might not be called the smart city if it is not safe for children. It is tried to offer common indices under the issue of urban planning. As the following diagram shows, urban planning has five main sub branches in urban form layer. In this study, two indices of the land application system and movement and access system are of greater importance. 


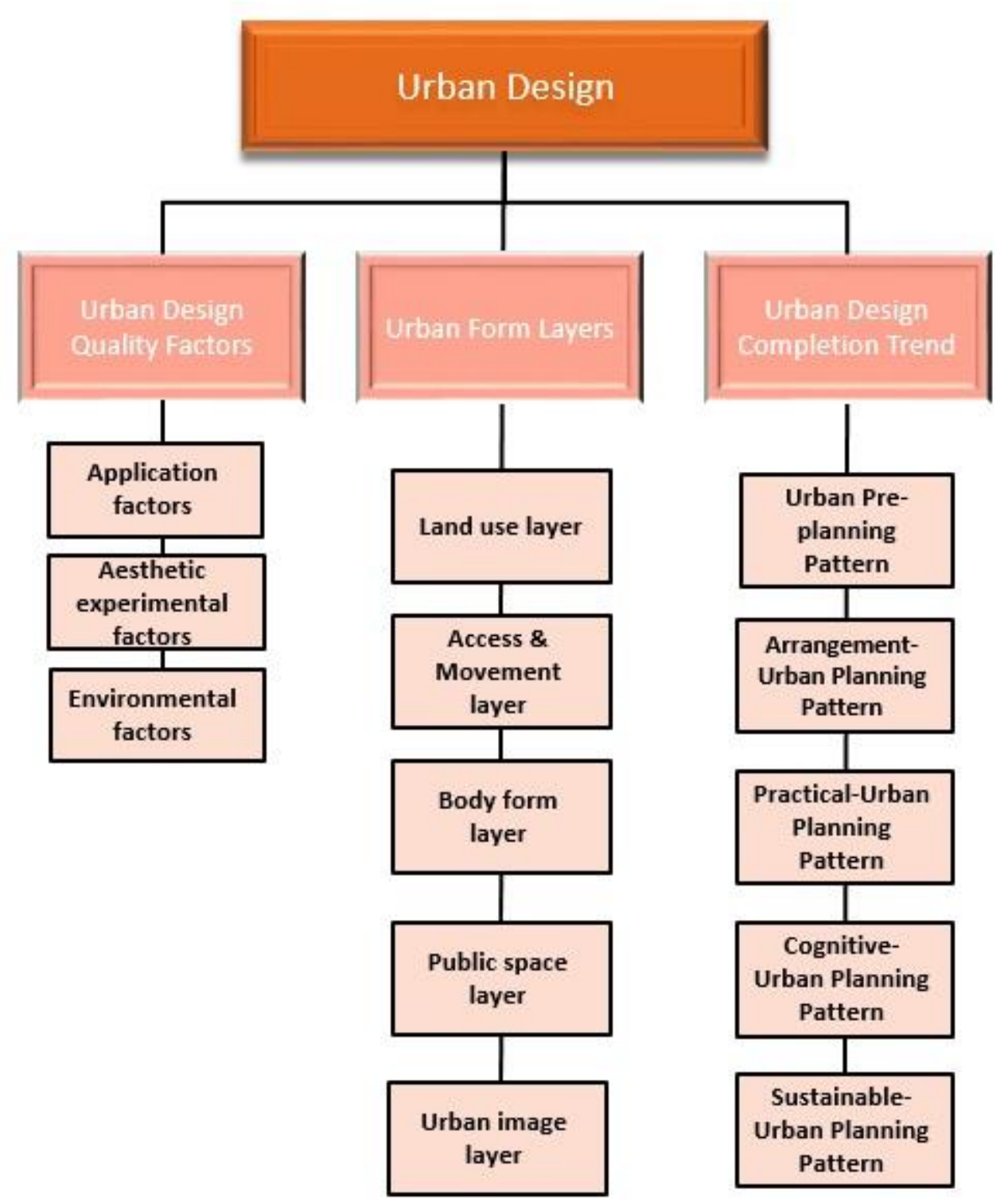

Diagram4: Urban Design Quality Factors, Urban Form Layers, Urban Design Completion Trend; Source: Researcher 
Table 5: Land application layer and movement and access layer to link the two concepts of smart city and CFC; Source: Researchers

\begin{tabular}{|c|c|c|}
\hline Explanation & $\begin{array}{l}\text { Urban } \\
\text { Form } \\
\text { Layer }\end{array}$ & \\
\hline $\begin{array}{l}\text { Focal consideration as the center of area in each area } \\
\text { The center of each area should be in a near distance to the edge of area or the farthest point of the } \\
\text { area ( } 400 \text { meters) so that children can walk } \\
\text { Using visual arts in urban spaces especially as a central factor might be memorable and attractive. } \\
\text { These arts increase the memory of cities by producing interesting pictures. Smart statues that react } \\
\text { when a person approaches them makes this possibility more }\end{array}$ & 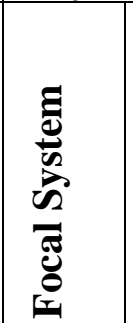 & \\
\hline $\begin{array}{l}\text { Positioning of primary schools near science-technology centers for more relationship of children } \\
\text { with empirical sciences } \\
\text { Attempt to elevate the possibility of cyber educations and distant education } \\
\text { - Possibility of education in spaces that are not necessarily for education for example through } \\
\text { smart educational signs in a way that is observable by children }\end{array}$ & 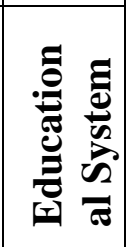 & \\
\hline $\begin{array}{l}\text { Considering science-technology parks and developing them as centers that have a suitable } \\
\text { invitation for children. } \\
\text { In designing children's play space, using natural elements such as water makes the space more } \\
\text { attractive and enhances their spirits } \\
\text { Designing and using sports tools and smart games that prevent any damage to children by sensitive } \\
\text { sensors }\end{array}$ & 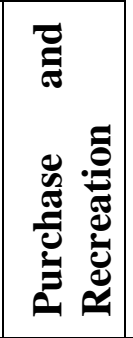 & 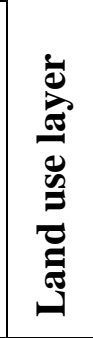 \\
\hline $\begin{array}{l}\text { Given the inability of children to read information signs and traffic ones, urban planners should } \\
\text { look for other strategies to deal with this problem. For example, using simple visual signs could be } \\
\text { a solution }\end{array}$ & 章 & \multirow[b]{4}{*}{$\frac{\dot{\Xi}}{e^{2}}$} \\
\hline $\begin{array}{l}\text { To increase interest in biking, path ways should be designed in a way that has suitable slope for } \\
\text { biking and at the same time, related technological signs should also be used } \\
\text { Smart bike stations make it possible for children to use bikes without presence of any person by } \\
\text { pulling a card }\end{array}$ & 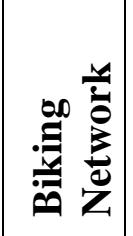 & \\
\hline $\begin{array}{l}\text { Access paths to public transportation should be short from schools and they should also be safe at } \\
\text { different times. } \\
\text { Smart lighting in children's paths increases security. Smart lamps should be used that are in line } \\
\text { with the extent of darkness. } \\
\text { Smart guards that increase security as well } \\
\text { Placement of smart boards in children's pathways might make the way more attractive to them and } \\
\text { also teaches some points to them }\end{array}$ & 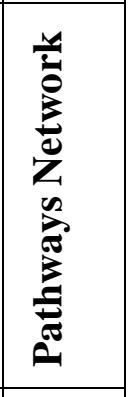 & \\
\hline $\begin{array}{l}\text { Using new technologies such as electronic, information, and other types of technology improve } \\
\text { Transportation, security, safety, and efficiency and it might also improve other factors such as } \\
\text { reduction of energy consumption and environmental indices including weather quality. } \\
\text { As human resources decrease in processing of information and controlling and managing processes } \\
\text { decrease, decision-making process improves. Besides, security maximizes for children in public } \\
\text { transportation. } \\
\text { Smart stands that adapt with addresses' height make it possible for children to get their intended } \\
\text { tickets or become aware of movement times. Additionally, smart transportation system makes it } \\
\text { possible to increase the width of walking pathways. }\end{array}$ & 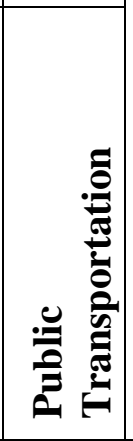 & \\
\hline
\end{tabular}


From a psychological perspective, "meaning comprehension" is achieved by indirect knowing or movement in opposite direction of happenings. In other words, when a person is in direct relationship with an issue, no complete knowing is achieved. Therefore, children will learn about the meaning and value of a relationship with the place, only after reflection of the environment in their experiences as awareness at time direct experience reaches its least extent to the extent that encountering with the world appears almost usual and unconscious. Indirect knowing makes it possible for children to reflect the experience of place in their mind and determine their own relationship identity through experience. The important issue to conceptualize amenity with a place in childhood is that children make a desirable emotional relationship with places that meet their needs and wishes in their growing process.

Green spaces are one suitable place in which the interaction and participation of children about environmental decisions. Thus, from one hand, green space, as one of the children interesting spaces, might enhance their motivation for participation in the planning of cities and on the other hand, it leads to the participatory atmosphere between children and other age groups.

The way of green space besieges, color and light in space, relationship of green space with artificial spaces, genders, and expediencies, relationship of children spaces and adults spaces, car, and bike, place of trees and flowers and relationship with school are among factors that children pay attention to and shown in the following diagram.

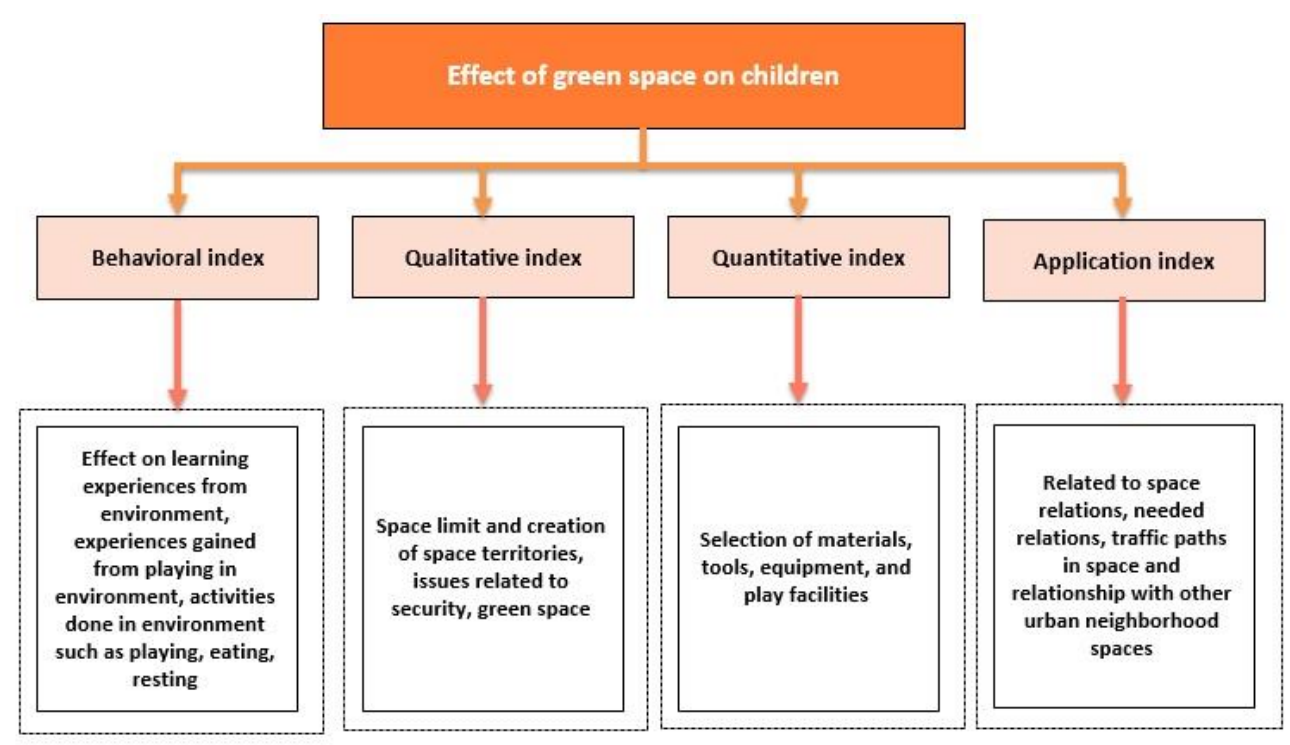

Diagram 5: Examination of Green Space on Children (Researchers)

Additionally, the existence of visual arts in urban space causes that not only urban space becomes softer despite its chaos, but also, makes it possible for art to enter cities. This idea has long been taken into consideration by many urban planners. 

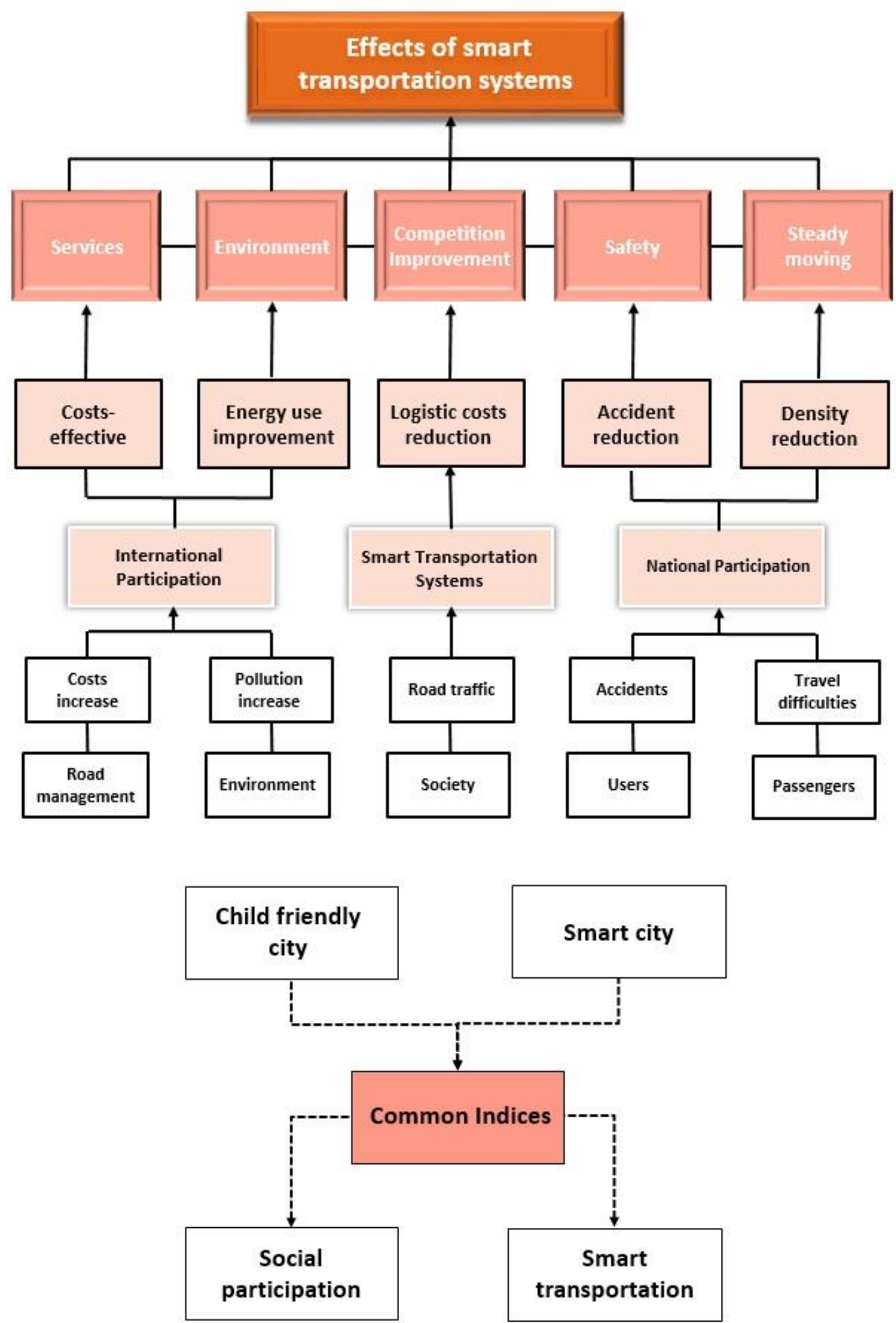

Diagram 6: Summarization of Research Stages (Researchers) 


\section{References}

1. Ghanbari, Hakimeh 2011. Theory of smart city and urban governing.

2. Razaghi, Nasim, 2016. Examination of smart city, International conference of computer and information technology engineering, Tehran. Conference eternal secretary.

3. Rahnama, Rahim \& Hayati, Salman 2013. Analysis of growing indexes of smart growing in Msashhad, Urban Planning Studies Quarterly, Year 1, No. 71-98.

4. Reneh Short, John, 2016. Critical Evaluation Urban Theory. Translated by Karamat Allah Ziari. Tehran University Publications. Edition 3.

5. Kiani, Akbar \& Ali Esmaieelzadeh Kavaki, 2012. Analysis and planning CFC from Children's attitude, Case study: Ghoochan, Bagh Nazar Quarterly, 9.

6. Khoshnevis, A. 2009. Architecture for children. Translation. Ganj Honar Publications.

7. Azmoodeh, M. 2009. Designing children museum garden in Tehran western town, M.S. Thesis, Tehran University.

8. Kamel Nia, H. \& Haghir, S. 2009. Pattern sof designing green space in CFC (Case study: Bam CFC). Bagh Nazar, No. 12, Year 6. 78-88.

9. Ebrahimi, H., Saeedi Rezvani, N., Maani, Manjiili, A. 2011. Compiling the principles of designing children play space with an emphasis on age group off 5 to 12 years old. Case Study: Rasht city. Bagh Nazar, No. 8, 31-42.

10. Karbalaie Hasani Ghiasvand, Abolfazl. Soheili, Jamalodin. Examining the features of lovely city from children's attitude. Case study: Ghazvin municipality, the second area. Urban Studies Magazine, winter 2013, No. 9.

11. Zekavat, K. 2006. Strategic framework of city visual management. Abadi Magazine, No. 53, 32-45

12. Mardomi, K., Ebrahimi, S. 2013. Play motivation, strategy of designing learning environments. Iranian Architecture and Urban Building Scientific Association Magazine, No. 5, 109-120.

13. Masihpour, Mohammad Hossein \& Mojtaba Akbarian, 2016. Intelligence of cities: necessity of creating electronic city. International conference on management and industries engineering, Tehran, Conference eternal secretary.

14. Momeneh, Mohammad Saeed \& Korosh Rostam Pourzolani. 2016. Smart city equals with sustainable development. The third scientific-research conference on new horizons in geography sciences and Iranian urban building nad architecture planning. Tehran, Association of development and prevalence of fundamental sciences.

15. Hasanpour, Shahab; Mohsen Safari \& Mojtaba Goudarzi. 2016. Evaluation of smart systems of transportation in urban traffic. The fourth national conference of sustainable development in Geography sciences and architecture and urban building. Tehran, Mehr Arvand high education institution, Access strategies center.

16. Momeneh, Mohammad Saeed \& Korosh Rostam Pourzolani, 2016. Management of cities by idea of smart city. The third scientific-research conference on new horizons in geography sciences and Iranian urban building and architecture planning. Tehran, Association of development and prevalence of fundamental sciences.

17. Poursharifi, Javad \& Masoomeh Jafari. 2016. Evaluation and equipment of smart cities with economic approach. International convention on urban economy. Tehran, Iranian Urban Economic association.

18. Dehnaie, Morteza. Making added values from information data. Transportation magazine, 2014. 
19. Sadeghzadeh, Ramezan Ali. Rasouli, Farhad. Firoozi, Fatemeh. Development of electronic city. The second international conference of electronic municipality. Information technology and communication research house of ACECR. Tehran Municipality. 2012, the second edition.

20. Shahidzadeh, Hossein. Asgarinehad Amiri, Ali. Comprehensive Urban ITC plan. Traffic news Quarterly. 2013. No. 43.

21. Unies, Nations. "Rapport sur la troisieme session du Forum Urbain Mondial." (2006).

22. Zhao, P (2010). Sustainable urban expansion and transportation in a growing megacity: Consequences of urban sprawl for mobility on the urban fringe of Beijing, Habitat International, 34 (2), 236-243

23. Lopez R (2014). Urban Sprawl in the United States: 1970-2010, Cities and the environments, 7(1), 224

24. Droege, p.2007: Intelligent Environment, Amsterdam, Elsevier Science B.V.

25. Cocchia, Annalisa. "Smart and digital city: A systematic literature review." Smart city. Springer International Publishing, 2014. 13-43.

26. Bowerman, B., et al. "The vision of a smart city." 2nd International Life Extension Technology Workshop, Paris. Vol. 28. 2000.

27. Gabrys, Jennifer. "Programming environments: Environmentality and citizen sensing in the smart city." Environment and Planning D: Society and Space 32.1 (2014): 30-48.

28. Batty, Michael, (2005), Cities and Complexity. The MIT Press, Cambridge, Massachusetts.

29. Madakam, Somayya, and R. Ramaswamy. "100 New smart cities (India's smart vision)." Information Technology: Towards New Smart World (NSITNSW), 2015 5th National Symposium on. IEEE, 2015.

30. Aijaz, Rumi, and Kristian Hoelscher. "India's Smart Cities Mission: An Assessment." ORF Issue Brief 124 (2015).

31. Bartlett, Sheridan. "Building better cities with children and youth." (2002): 3-10.

32. HUTTON,J. Imoriving highway safety eith ITS, 2003

33. Stefansson, Gunnar, and Kenth Lumsden. "Performance issues of smart transportation management systems." International Journal of Productivity and Performance Management 58.1 (2008): 55-70.

34. Rudd, James HF, et al. "Atherosclerosis inflammation imaging with 18F-FDG PET: carotid, iliac, and femoral uptake reproducibility, quantification methods, and recommendations." Journal of Nuclear Medicine 49.6 (2008): 871-878.

35. World planing Organization, United Nations Population Fund, and Key Centre for smart cities. $a$ global review of the literature. World cities planing Organization, 2009.

36. Dirks, Susanne, and Mary Keeling. "A vision of smarter cities: How cities can lead the way into a prosperous and sustainable future." IBM Institute for business Value 8 (2009).

37. https://bernardvanleer.org/cases/indias-first-smart-and-child-friendly-city/ 